\title{
WEB BOOK ORDERING USING ONLINE BOOKSTORE SYSTEM
}

\author{
Harshi Gupta \\ BCA(SCSE) \\ Galgotias University, Bulandshahr, U.P., India \\ Isha Agarwal \\ $\mathrm{BCA}(\mathrm{SCSE})$ \\ Galgotias University, Jhansi, U.P., India
}

\begin{abstract}
The Internet by a wide margin assumes a significant part in individuals' life. It has radically improved the personal satisfaction also, the way of life of such countless individuals. It has augmented its branches into various levels and zones. The web based business industry is one such branch which has come into spotlight in the new years. The on the web book shop framework has facilitated the existence of so many book darlings by making it simple for them to buy books on the web. It is not generally practical to get to a customary book shop, it is restricted by its activity time, accessibility of a specific book, its area and in particular its ability and the space needed to store various books. Such downsides have prompted the development of online business businesses identified with book shops. Our undertaking is one such straightforward internet business site which houses different books of various classifications for a buyer to buy on the web.
\end{abstract}

Keywords - Internet, online business, customary book shop, online book shop, site.

\section{INTRODUCTION}

In this period of profoundly progressed programming, one can notice a great deal of progress in the zone of engineering plan and its standards. There are different inventive and effective programming arising out in the market which have made the existence of an average person straightforward and simple. Our Online Bookstore is one such programming. It is a blend of both internet business and book deals industry set up in a solitary programming. Utilizing the online book shop framework has a great deal numerous benefits. There is definitely no need for a buyer to go out searching for a specific book.

The book of his/her enjoying can be effectively bought utilizing the on the web book shop programming while sitting in their customary range of familiarity furthermore, simply running the product on a framework with a functioning web association and an internet browser. This aides in saving a ton

\author{
Daksh Tomar \\ BCA(SCSE) \\ Galgotias University, Greater Noida, U.P., India \\ Mr. Praveen Dominic \\ Associate Professor(SCSE) \\ Galgotias University, Noida, U.P., India
}

of time and energy of the shopper. Building up an internet business site requires different pre-imperatives.

A plentiful measure of information on multi-layered design, worker and customer side scripting strategies, a portion of the usage methods like JSP, programming dialects, for example, Java, JavaScript, HTML and data set methods, for example, MySQL and Microsoft Access are required. Our undertaking is planned also, actualize utilizing HTML and PHP dialects. The data set is overseen utilizing MySQL and the customer worker correspondence is taken care of by XAMPP.

The target of our venture is to build up a fundamental online business site for the deals of books over the web. The site permits a client to look for various books of various classes which are accessible for procurement. It facilitates the strategy of buying by permitting the client to add the book of his/her preferring into a shopping basket. The client can at that point complete the buying by making an exchange with a credit/charge card or by essentially picking money on conveyance.

\section{SYSTEM DESIGN AND IMPLEMENTATION}

- HTML and PHP language are utilized for the plan what's more, usage of the website page of the project.

- MYSQL is utilized for making the information base of the framework.

- XAMPP is utilized for customer worker correspondence.

1) SYSTEM DESIGN-

\section{A. Home page:}

This is the underlying page shown after client signing in effectively. It will show the most recent books with name furthermore, picture which are accessible in the store and it has four choices Publisher, Books, Contact, my Cart. 


\section{International Journal of Engineering Applied Sciences and Technology, 2021 \\ Vol. 5, Issue 10, ISSN No. 2455-2143, Pages 203-207 \\ Published Online February 2021 in IJEAST (http://www.ijeast.com)}

\section{B. Distributer:}

It shows the rundown of the distributer of a specific book. It contains all the names of the distributers which are accessible in Online Book Store. Also, again if the client taps on distributers name it shows the book alongside picture and the client can get the subtleties of the book and can likewise add to truck.

\section{Books:}

In this segment client can see the all books accessible in the Store.

\section{Contact:}

It has three choices Name, Email, Text zone. Name ought to be loaded up with the client name with second name and in email segment client needs to give their email to get request effective message and the content zone is the place where the clients can enquire about the subtleties of the book to be conveyed.

\section{E. My Cart:}

In My Cart the client will have the option to get to a shopping truck that contains all the books he/she has chosen. The client will ready to see the book with book name, distributer name, value, amount and absolute cost and client are permitted to add or erase a book. In the full review the My Cart contains all the things chose by the client and all out expense of the chose things is shown.

\section{F. Rating:}

The clients are permitted to give book rating dependent on their past bought history. They can rate it by giving five for awesome, four for great, three for great, two for ordinary and one for low.

\section{G. Administrator Login:}

The Admin Login has the uncommon capacities like

- Adding new book into the shop.

- Deleting the book which are not accessible in shop.

- Deleting the unauthenticated client the site of the book shop.

- Adding another classification of the books

\section{2) SYSTEM INTERFACE DESIGN-}

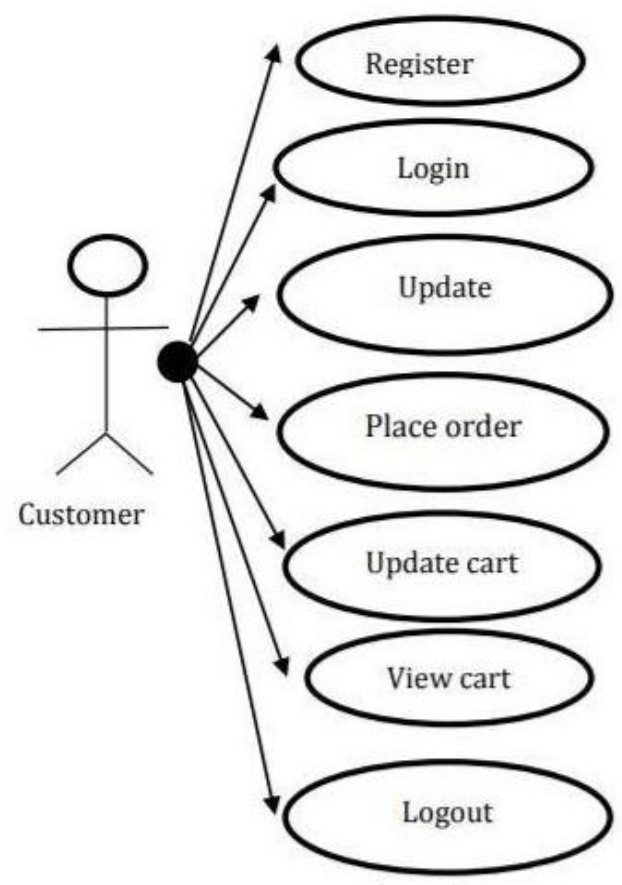

Figure-1

\section{A. Register}

- Use: When the client doesn't have an account then the client will have the option to make one.

- Actor: Customer.

- Input: Customer should embed subtleties in the enlistment structure. That incorporates
1. Client name
2. Secret word
3. Adjust secret word
4. First name
5. Last name
6. Email address
7. Address
8. Phone
9. Data of installment card

\section{B. Login}

- Use: If the client needs to utilize any of the functionalities of the Online book shop, he must login with his username and secret word.

- Actor: Customer.

- Input: User name and secret word.

- $\quad$ Output: if the username and secret word are right then he is diverted to landing page else provoked to reemerge the client subtleties. 


\section{Update profile}

- Use: If the client needs to refresh their record data, they can refresh their picked fields what's more, change all the information in the data set with an refreshed inquiry.

- Actor: client.

- Input: Users update their record subtleties.

- $\quad$ Output: The program refreshes the subtleties entered in the information base utilizing an update technique.

\section{Submit a request}

- $\quad$ Use: If the client wishes to buy a book, they can put in the request by tapping the add to the shopping basket button and embeddings the total required under the book portrayal.

- Actor: Customer.

- Input: The client should press the shopping truck catch to cooperate.

- $\quad$ Output: The request will be added to your shopping basket.

\section{E. Update Shopping Cart}

- Use: The client can ready to change the book or on the other hand change the amount of the book.

- Actor: Customer.

- Input: The client taps on the data button in the shopping basket assortment to adjust furthermore, right the request information.

- $\quad$ Output: The subtleties of the updated request are shown in the depiction of the shopping truck.

\section{F. View Shopping Cart}

- Use: When the client needs to see the thing he/she has joined to the shopping basket, he/ she will at that point press the catch at the highest point of the list.

- Actor: client.

- Input: At the highest point of the page the client taps on the shopping basket button.

- $\quad$ Output: Shopping truck diagram of the client would be appeared in an even arrangement of all the books and their volumes with costs.

\section{G. Logout}

- Use: When the client needs to end the meeting and to sign out of the site, he may utilize the logout technique.

- Actor: Customer.

- Input: Consumer presses the catch to logout.

- $\quad$ Output: The record meeting of the client lapses .

\section{3) ADMINISTRATOR DESIGN-}

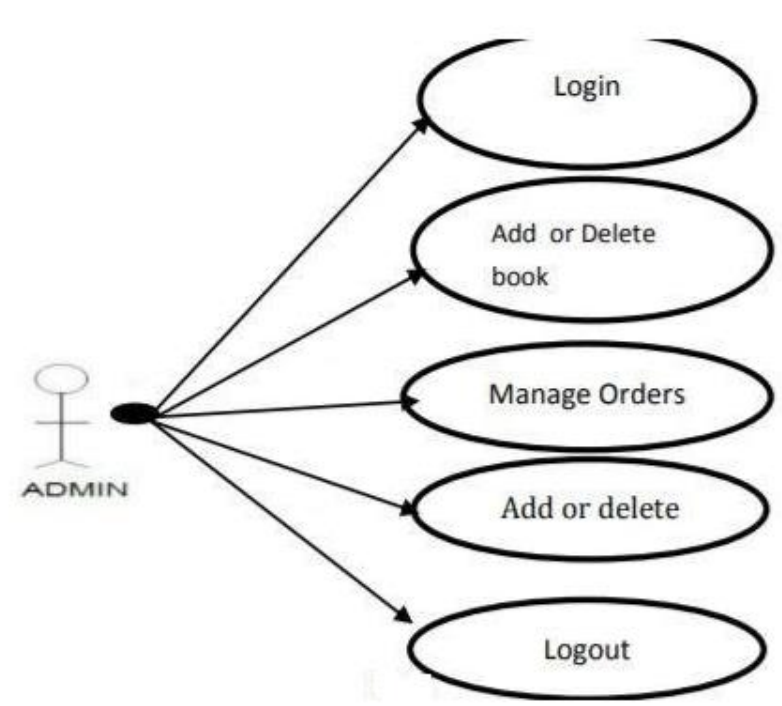

Figure-2

\section{A. Login}

- Use: permits the Administrator to get to all the functionalities of Online Book Store by logging into the record utilizing the username and secret key.

- Actor: Admin

- Input: the username and secret key of the overseer.

- Output: if the username and secret key are right then he is diverted to landing page else provoked to return the login subtleties

\section{B. Add or Delete Book}

- Use: permits administrator to add or erase a book structure the list then he can embed a book or erase a book utilizing the privileges of the head and the book subtleties will be refreshed in the site and data set.

- Actor: Admin.

- Input: the Administrator can add a book the by tapping the supplement button in the book page and give the accompanying subtleties identified with the book
1 Title
2 Creator
3 Cost
4 Picture
5 Distributer

He can erase a book by tapping the erase button from the book page to eliminate the book from site inventory and data set.

- Output: The new books inventory is shown in the site under the classification indicated by the head

\section{The executives of the Orders}




\section{International Journal of Engineering Applied Sciences and Technology, 2021 \\ Vol. 5, Issue 10, ISSN No. 2455-2143, Pages 203-207 \\ Published Online February 2021 in IJEAST (http://www.ijeast.com)}

- Use: the head can eliminate or add an request, he can do this by his administration rights.

- Actor: Admin.

- Input: the Administrator can append a request by tapping the addition association button on the request tab, at that point the chose request might be taken out

- Output: the last amended request rundown will be prepared for additional utilization

D. Add or erase cc (credit card)

- Use: If a CC structure is added or taken out by the head, the $\mathrm{CC}$ structure might be embedded or taken out utilizing by utilizing the organization rights and the CC table is changed in the information base of the site

- Actor: Admin.

- Input: the head can add a CC sort by tapping the supplement association button on the $\mathrm{CC}$ page or he can likewise erase a specific CC sort by choosing and eliminating it from the information base.

\section{E. Logout}

- Use: Used to end the administrator meeting from the site by clicking logout choice.

- Actor: Admin.

- Input: By tapping the logout .

- Output: When The c Admin taps the logout button the record meeting reaches a conclusion.

\section{MAIN REQUIREMENTS}

\begin{tabular}{|c|c|}
\hline Hardware requirement & Software requirements \\
\hline $512 \mathrm{mb}$ of ram & $\begin{array}{l}\text { My SQL: it is a Relational } \\
\text { Database Management } \\
\text { System (RDBMS) }\end{array}$ \\
\hline \multirow[t]{3}{*}{$\begin{array}{l}\text { Dual core processor or } \\
\text { higher }\end{array}$} & $\begin{array}{l}\text { PHP: it is programming } \\
\text { language used for } \\
\text { backend programming. }\end{array}$ \\
\hline & $\begin{array}{l}\text { Web browser: used to } \\
\text { access the website. }\end{array}$ \\
\hline & $\begin{array}{l}\text { XAMPP: It is an } \\
\text { application that helps you } \\
\text { to quickly customize a } \\
\text { web server and database. }\end{array}$ \\
\hline
\end{tabular}

Figure-3

\section{CONCLUSION}

Online book shop has numerous focal points contrasted with its partners, for example, actual book shop, the on the web book shop permits it's client to shop at one spot where in actual store the books are dissipated at the unique places which devours a ton of time and on the web book shop helps in saving that time and it likewise dodges the issue of inaccessibility of books at actual store as various merchants from better places sell their books at one spot. This venture is productive in looking after clients records and can perform procedure on it, additionally diminishes the remaining burden on the retailer of knowing the amount of books accessible and which books are accessible and keeps the records of the number of books are bought and sold.

\section{REFERENCES}

1. Jiee Liiu.Design and Implementation of Online Bookstore Based on JSP and JavaBean Technology.Modern Information, 2014,(12):44-46.

2. Linvxi Meng.Design of Online Bookstore System Based on B2C Model.Valu engineering,2012,(35):101-102.

3. Yingqiian Tan.Research on Evaluation Index System of Online Bookstore Based on University Students' Satisfaction.Journal of Sun Yat-sen University (Social Science Edition),2012,(3):173-185.

4. Yinhuii Xu.Design and Realization of Online Used Book Sale System.Consumer Electronics,2012,(9):67-68.

5. Pazz Ajax and jQuery.Beginning Asp Net Mvc,2012,(2):12-14.

6. Dan Deeng.The Operating Mode and Development Prospect of China 's Online Bookstore.Entrepreneur World,2013,(3):112-114.

7. Ms. Pragrati Baagmare, Ms. Shradha Girthepunje "Research Paper on Online Bookshop Management System", International Journal for Research in Applied Science \& Engineering Technology (IJRASET), Volume 4, Issue 3, 2014, page no. 113-116.

8. Hani Maleni, Abduul Rahmani, "e-Bookstore: Opening Door to the Garden of Knowledge", International Journal of Scientific and Research Publications, Volume 5, Issue 4, June 2016 ,page no. 2251-3152

9. Vaamsi Krishna,A Report Submitted in partial fulfillment of the requirements of the degree of master of software engineering.

10. Reshaamm Shiinde, Priyaank Thaakre,"Design \& Implementation of Digital book ordering in Bookstores using web", International Journal of Advance Research in Computer Science \& Management Studies 2016.

11. Ashutosh Rana, Niranjana Jadhav,"Digital book ordering in Bookstores Using web", International Journal of Scientific \& Research Publications 2012. 
International Journal of Engineering Applied Sciences and Technology, 2021

Vol. 5, Issue 10, ISSN No. 2455-2143, Pages 203-207

Published Online February 2021 in IJEAST (http://www.ijeast.com)

12. Ayob Jiin, Mohd.Helmi Wahab,'The Application of Wireless Web Book Ordering System" MASAUM Journal of Computing 2007.

13. Vengatsaan, A Study on Consumer Buying Behavior of Kid's Product with Special Reference to Coimbatore City, International Journal of Applied Research 2013. 